\title{
Article \\ Electrosynthesis and Characterization of Novel CNx-HMMT Supported Pd Nanocomposite Material for Methanol Electro-Oxidation
}

\author{
Faizah Altaf 1,2,3,*, Rohama Gill ${ }^{1}$, Patrizia Bocchetta ${ }^{4}\left(\mathbb{D}\right.$, Rida Batool 1,3,5, Muhammad Usman Hameed ${ }^{2}$, \\ Ghazanfar Abbas ${ }^{3}$ and Karl Jacob ${ }^{5, *}$
}

\section{check for}

updates

Citation: Altaf, F.; Gill, R.;

Bocchetta, P.; Batool, R.;

Hameed, M.U.; Abbas, G.; Jacob, K.

Electrosynthesis and Characterization

of Novel CNx-HMMT Supported Pd

Nanocomposite Material for

Methanol Electro-Oxidation. Energies

2021, 14, 3578. https://doi.org/

$10.3390 /$ en14123578

Academic Editors: Vladimir Gurau and Jinliang Yuan

Received: 13 May 2021

Accepted: 10 June 2021

Published: 16 June 2021

Publisher's Note: MDPI stays neutral with regard to jurisdictional claims in published maps and institutional affiliations.

Copyright: (c) 2021 by the authors. Licensee MDPI, Basel, Switzerland. This article is an open access article distributed under the terms and conditions of the Creative Commons Attribution (CC BY) license (https:// creativecommons.org/licenses/by/ $4.0 /)$.
1 Department of Environmental Sciences, Fatima Jinnah Women University, Rawalpindi 46000, Pakistan; rohamag@gmail.com (R.G.); ridabatool658@gmail.com (R.B.)

2 Department of Chemistry, Women University Bagh, Azad Jammu and Kashmir 12500, Pakistan; usmanhamid506@gmail.com

3 Department of Physics, Lahore Campus, COMSATS University Islamabad, Lahore 54000, Pakistan; drghazanfarabbas@ciitlahore.edu.pk

4 Dipartimento di Ingegneria dell'Innovazione, Università del Salento, via Monteroni, 73100 Lecce, Italy; patrizia.bocchetta@unisalento.it

5 Georgia Institute of Technology North Avenue, School of Mechanical Engineering, Atlanta, GA 30332, USA

* Correspondence: faizahaltaf@gmail.com (F.A.); karl.jacob@mse.gatech.edu (K.J.)

Abstract: In the current research work, palladium (Pd) nanoparticles were electrochemically deposited on a nitrogen doped montmorillonite (CNx-MMT) support using the underpotential deposition (UPD) method. The prepared Pd based composite electrode was studied as an electrocatalyst for methanol fuel oxidation. The catalysts and the supporting materials montmorillonite, acid activated montmorillonite, and nitrogen doped montmorillonite (MMT, HMMT and CNx-HMMT) were characterized by Fourier transform infrared spectroscopy (FTIR), X-ray diffraction (XRD), scanning electron microscopy (SEM), and energy dispersive X-ray spectroscopy (EDS) and electrochemical characterization by cyclic voltammetry $(\mathrm{CV})$. The results indicated that Pd supported on CNx-HMMT possesses enhanced electrocatalytic activity and stability compared to commercial $\mathrm{Pd} / \mathrm{C}$, which was attributed to its higher electrochemical surface area (ECSA) $\left(23.00 \mathrm{~m}^{2} \mathrm{~g}^{-1}\right)$. The results demonstrated the potential application of novel Pd/CNx-HMMT composite nanomaterial as electrocatalysts for methanol electrooxidation in direct methanol fuel cells (DMFCs).

Keywords: direct methanol fuel cell; nitrogen doped montmorillonite; underpotential deposition; electrocatalyst; methanol electrooxidation

\section{Introduction}

Recently, methanol electro-oxidation has acquired considerable interest due to its possible application in direct methanol fuel cells (DMFCs), which are well-matched for portable power applications where the power supplies are low and a simple compact system having high energy density is necessary [1,2]. They offer distinctive benefits such as ready accessibility and the safe storage and transport potential for liquid fuel methanol. However, the commercialization of DMFC is strictly limited by the kinetic loss related to the charge transfer of the methanol oxidation half reaction that shortens the power output of the fuel cell $[3,4]$.

Usually, Pt-based electrocatalysts have been used for methanol electro-oxidation in acidic media $[5,6]$. However, the high price and inadequate resources inhibit the practice of Pt at a commercial scale. Moreover, the Pt-based electrocatalysts are usually subjected to deactivation due to poisoning by the reaction intermediates or fuel impurities, such as carbon monoxide. The degradation of electrocatalysts generally comes in two ways: (1) metal (platinum), agglomeration, sintering, and/or dissolution resulting in loss of 
catalyst active area, and (2) support-corrosion mechanisms leading toward degradation of the catalyst.

The conventional carbon support undergoes electrochemical corrosion which has been proved to be the main cause of durability decrease in Pt-based electrocatalysts [7]. The support should be corrosion-free and stable enough for electrocatalysts to make DMFC technology economically viable. The synthesis of durability stable anode catalysts with adequately high electrocatalytic activity is particularly challenging [8].

A promising approach for addressing these challenges is the preparations of $\mathrm{Pt}$ alloys with other elements [9]. Pt and Ru have been generally recognized as the best electrocatalysts toward methanol oxidation thanks to their great performance in terms of electrocatalytic activity and durability [8,10]. However, practical applications of $\mathrm{Pt}$ and $\mathrm{Ru}$ materials in DMFC are strongly limited by their high cost. Another strategy aimed to decrease the costs is the use of $\mathrm{Pt}$ free catalysts. In this regard, a great deal of interest has been concentrated on Pd-based metals due to the good electroactivity of Pd toward methanol and ethanol oxidation. Some benefits of substituting Pt with Pd material as anodic material for DMFC are the structural resemblance between the two metals, the main availability and low price of Pd due to the abundant mining sources of palladium that reduce the costs up to 2.7 times with respect to $\mathrm{Pt}$. In addition, palladium showed high catalytic activity for the oxidation of many alcohols and more resistance to CO poisoning [5].

Pd-based catalysts have been proven to succeed in delivering high anodic performance in DMFCs [11-13]. However, the activity and stability of the Pd catalyst can be further improved by replacing the conventional carbon support for Pd catalysts with novel carbon materials subjected to relevant treatments, such as doping with nitrogen and metal oxides $[14,15]$ with the aim of tailoring the catalytic support properties. Particularly, nitrogen doping is more prominent [16], which modifies the electronic properties of carbon, for example by inducing n-type electrical conductivity. In addition, $\mathrm{N}$-doping improves the chemical capability of pristine carbon to favor the catalyst deposition process by nucleation and growth. As a consequence, the modified bonds between N-doped carbon and the catalyst particles generate a better electrochemical activity and durability [17].

Vinayan et al. prepared palladium nanoparticles decorated nitrogen-doped graphene, and the electrocatalytic study of the Pd/N-G shows that it is a very good anode electrocatalyst. Wang et al. prepared nitrogen-doped graphene oxide/polyaniline composites and used them as supercapacitor electrodes [18]. The aniline monomer is mostly utilized for nitrogen doping because it increases the electrode kinetic, the surface area, electrical conductivity and corrosion resistance and the low-cost polymerization reaction $[16,19]$.

The catalyst support is recognized as having a great role in improving the catalytic performance and activity because the possible formation of bonds between the active sites and catalyst supports [20], the chemical features of the support, and surface area where the active particles can be uniformly dispersed. The main investigated supports for methanol oxidation electrocatalysis are based on $\gamma$-alumina [21], ceria [22], and mesoporous beta zeolite [23].

Among the possible support materials to be employed as anode catalysts for DMFC, clays are more effective. MMT is very inexpensive due to its availability. It also has numerous advantages including chemical inertness and environmentally friendly nature, which enable it as a promising support material for fuel cell applications. MMT, a 2:1 clay mineral is a member of the smectite group. Its layer consists of two tetrahedral sheets sandwiching a central octahedral sheet [24-26]. The use of MMT as a catalyst support has been reported in the literature. For example, with low-loaded Pt nanoparticles on intercalated MMT exhibited excellent selectivity and high conversion of the alcohols [27,28].

The electrocatalyst for $\mathrm{MeOH}$ can be more economical by reducing its amount using more advanced underpotential deposition (UPD). In underpotential deposition (UPD) one or two monoatomic layers of metal are deposited on the surface of another metal and are carried out by applying more positive potential than its equilibrium potential [29]. This procedure relates to different features, such as the electronegativity difference between 
two elements, and the repulsive forces among UPD atoms, and the attractive interaction M-S. The metal electrodeposition process must follow the conditions of electroneutrality. If the one metal $(\mathrm{M})$ has a different oxidation state from other metal $(\mathrm{N})$, the monolayer may not be complete. Figure $1 \mathrm{~b}$ showed a typical replacement of one metal by another one under UPD. For the activation of an area or a site, it should have exposure to the reactants, an electrical connection with the electrode, an ionic connection with the electrolyte, and should have adequate electrocatalyst to obtain the desired reaction speed. The thickness of these regions and the nature of these interfaces determine the efficiency of an electrochemical reaction in all types of fuel cells [30].

In the present work, we propose a novel composite material made of nitrogen-doped montmorillonite (CNx-MMT) and polyaniline (PANI) as support of palladium nanoparticles for electrocatalytic methanol oxidation reaction (MOR). Nitrogen-doped montmorillonite (CNx-MMT) was synthesized by pyrolysis of PNI/MMT at a higher temperature and polyaniline (PANI) was added to increase the activity of catalysts [31,32].

Pd nanoparticles were deposited for the first time using the UPD method on the PANI/CNx-MMT nanocomposites to develop Pd/PANI/CNx-MMT electrode used as an anode catalyst for methanol oxidation. The Pd/CNX-MMT catalysts exhibited excellent electrochemical catalytic activity toward methanol electrooxidation thereby demonstrating their potential for application in DMFCs.

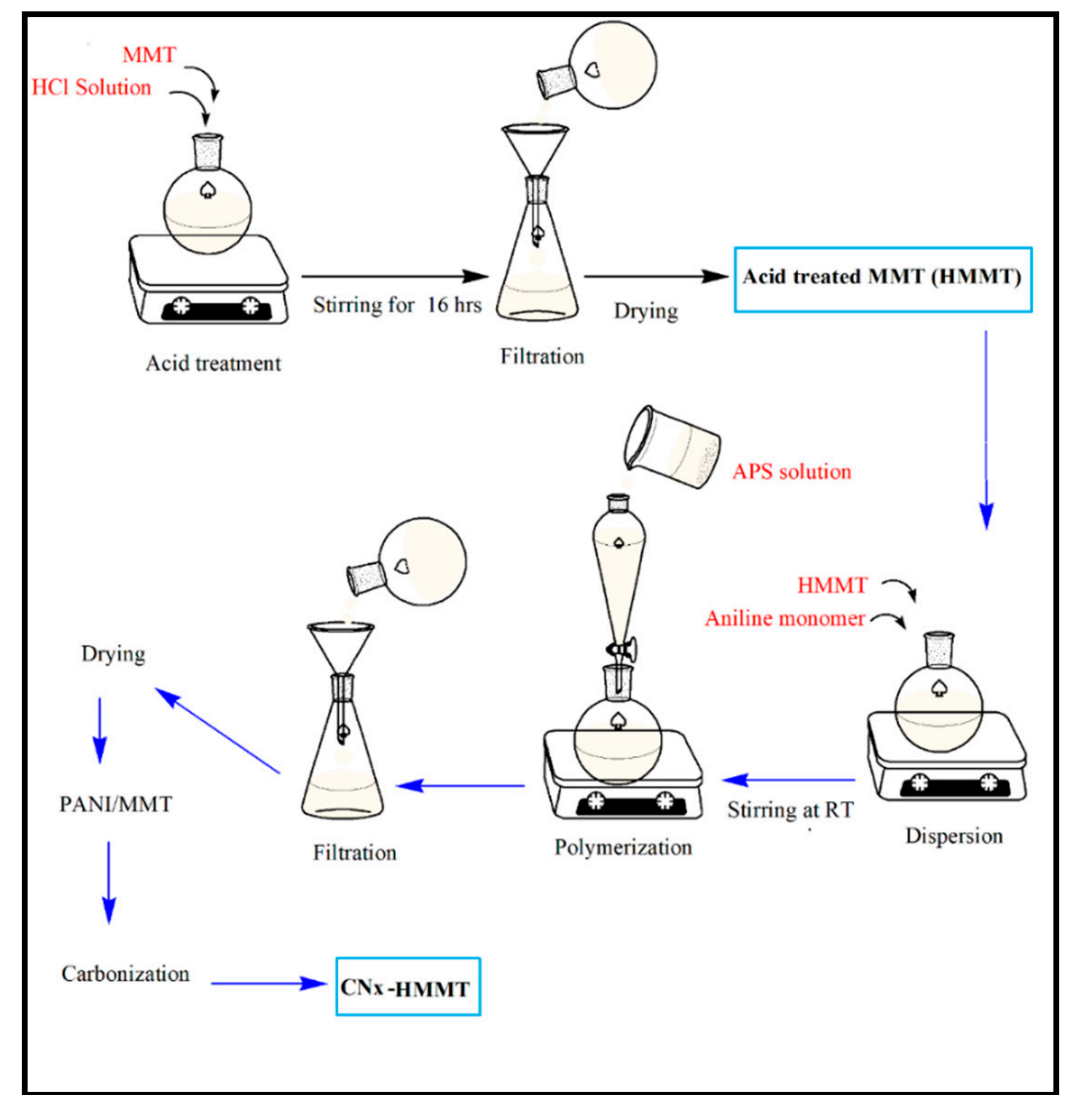

(a)

Figure 1. Cont. 


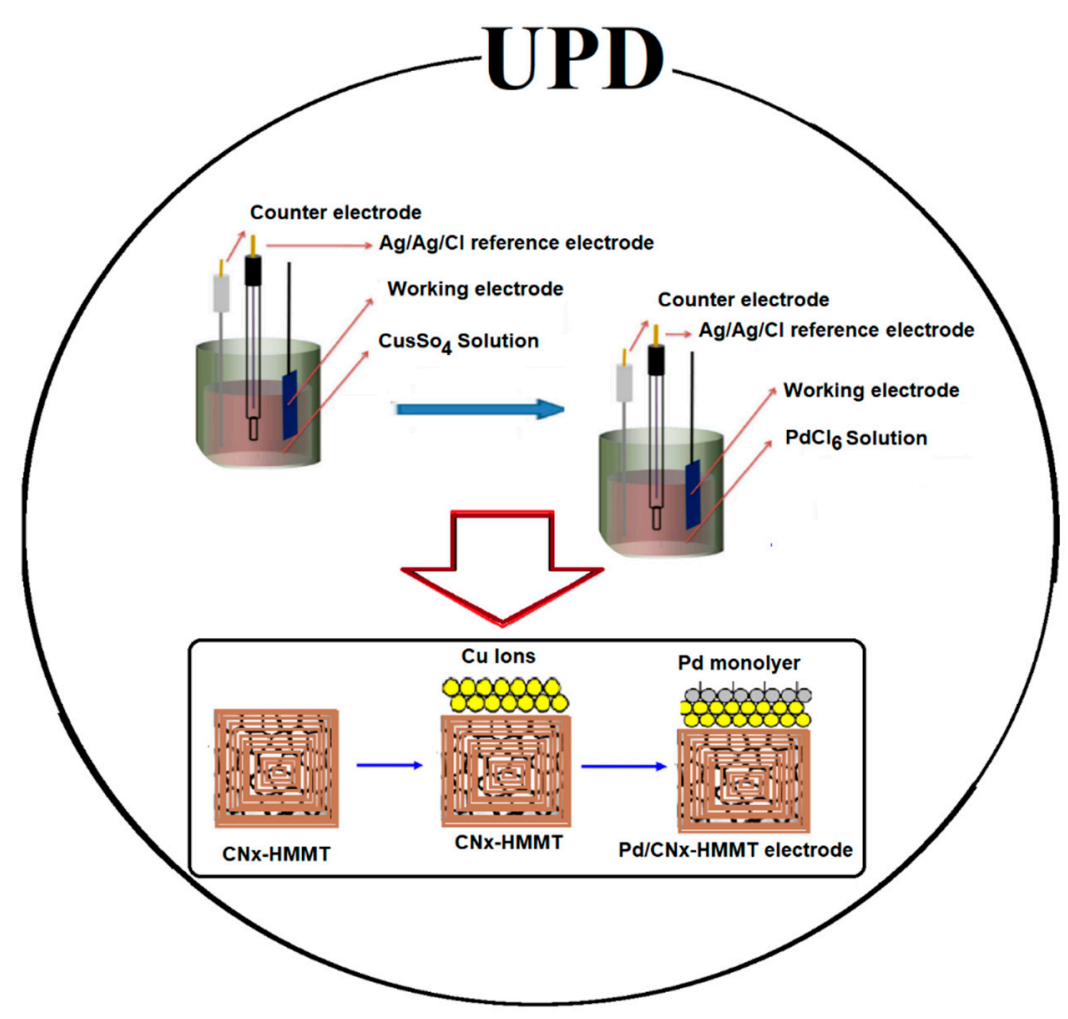

(b)

Figure 1. Synthesis of (a) nitrogen-doped electrocatalyst (CNx-HMMT) composite electrocatalyst, (b) Pd/CNx-HMMT composite electrocatalyst.

\section{Materials and Methods}

\subsection{Materials and Apparatus}

Aniline $\left(\mathrm{C}_{6} \mathrm{H}_{5} \mathrm{NH}_{2}\right)$ and MMT were supplied by Sigma Aldrich and Nanosabz Co, (Tehran, Iran). respectively. Ammonium persulfate (APS) $\left(\mathrm{NH}_{4}\right)_{2} \mathrm{~S}_{2} \mathrm{O}_{8}$, hydrochloric acid, methanol, $\mathrm{Pd}(\mathrm{II})$ chloride and sulfuric acid were purchased from Merck. All reagents were not subjected to any treatment before use. Double distilled water was employed in all the preparations.

\subsection{Synthesis of Pd-CNx-HMMT Composite Electrode}

The nitrogen-doped HMMT and Pd composite electrode was prepared using in situ emulsion polymerization method followed by underpotential deposition. The steps involved in the synthetic process of composite electrode are presented in Figure 1 and given below.

\subsubsection{Acid Activation}

The montmorillonite (MMT) clay was acidified using a previously published method [29,33]. For an acid treatment, $10 \mathrm{~g}$ of MMT was added into a $1000 \mathrm{~mL}$ flask, and then $500 \mathrm{~mL}$ of $3 \mathrm{M} \mathrm{HCl}$ was introduced into the flask and stirred for $16 \mathrm{~h}$ followed by filtration and washing with ultrapure water. The acidified MMT clay termed as acid activated montmorillonite (HMMT) was then vacuum dried at $80^{\circ} \mathrm{C}$ for further use.

\subsubsection{Synthesis of PANI/HMMT Nanocomposites}

An in situ polymerization was adopted for the preparation of PANI/MMT nanocomposites [30,31,34,35]. In this method, $2 \mathrm{~mL}$ of aniline monomer in $100 \mathrm{~mL}$ of $1 \mathrm{M} \mathrm{HCl}$ were vigorously stirred, and $20 \mathrm{wt} \%$ of MMT nano powder was added. Then $4.2 \mathrm{~g}$ of ammonium persulphate (APS) was added into $\mathrm{HCl}$ solution followed by stirring at room tempera- 
ture for $15 \mathrm{~min}$. After complete dissolution, the APS solution was added dropwise into aniline $\mathrm{HCl}-\mathrm{MMT}$ mixture and stirred continuously and maintained at $5{ }^{\circ} \mathrm{C}$. Polyaniline (PANI) formation from the aniline monomer via oxidation reaction was evident from the appearance of light blue coloration.

\subsubsection{Preparation of $\mathrm{CNx}-\mathrm{HMMT}$}

The reaction conditions were kept constant for $4 \mathrm{~h}$ to ensure a complete polymerization process, which was indicated by the appearance of dark green coloration due to the formation of PANI/MMT nanocomposites. Finally, the prepared nanocomposites solution was filtered followed by washing with distilled water 4 to 5 times to remove oligomeric strands and excess acid, then dried at room temperature. The final product was saved for further use.

Carbonization of PANI/MMT was performed by decomposing polyaniline at an elevated temperature. The carbonization process was carried out by keeping PANI/MMT in a quartz tube furnace and heating at $800^{\circ} \mathrm{C}$ for $2 \mathrm{~h}$. The heating rate was maintained to $5{ }^{\circ} \mathrm{C}$ min $^{-1}$ under $\mathrm{N}_{2}$ environment. The furnace was then switched off and a black powdery material coded as CNx-HMMT was collected [36].

\subsubsection{Fabrication of $\mathrm{Pd} / \mathrm{CNx}-\mathrm{HMMT}$ Thin-Film Electrode}

The nitrogen-doped Pd electrode (Pd/CNx-HMMT) was fabricated using the following steps: initially, a suspension of $\mathrm{CNx}-\mathrm{HMMT}$ was synthesized by dispersing $2 \mathrm{mg}$ of CNx-HMMT powder ultrasonically in $1 \mathrm{~mL}$ of Nafion and $1 \mathrm{~mL}$ of ethanol for about $15 \mathrm{~min}$. After complete dispersion, almost 10 microliters of suspension were shifted onto a glassy carbon disk with the help of a micropipette and was kept at room temperature for complete drying. To acquire the desired samples, the applied potential of $-0.35 \mathrm{~V}$ was set for $300 \mathrm{~s}$.

In the second step, the Pd layer was electrodeposited on CNx-HMMT using a technique similar to surface limited redox replacement (SLRR) for monolayer formation (Figure 1b). A Pine WaveNowXV potentiostat was utilized to carry out all electrochemical experiments. In the deposition process, the three-electrode cells were used. The first cell was filled with $10 \mathrm{mM} \mathrm{CuSO}_{4}$, the second cell contained $50 \mathrm{mM} \mathrm{H}_{2} \mathrm{SO}_{4}$ solution, and the third cell was filled with $0.05 \mathrm{PdCl}_{2}$. The Pt wire was utilized as a counter electrode, while $\mathrm{Ag} / \mathrm{AgCl}$ was used as a reference electrode. All the potentials values mentioned in the paper are intended to be referred to the $\mathrm{Ag} / \mathrm{AgCl}$ scale. The $\mathrm{CNx}$-HMMT composite was used as working electrode and was set up in hanging meniscus in three-electrode cell. All three solutions were purged with $\mathrm{N}_{2}$ gas for at least $15 \mathrm{~min}$ before starting the deposition process. The working electrode was immersed in $\mathrm{H}_{2} \mathrm{SO}_{4}$ solution in order to remove impurities. Initially, the working electrode was deposited by a few atoms of $\mathrm{Cu}$ via bulk $\mathrm{Cu}$ deposition in the $10 \mathrm{mM} \mathrm{CuSO}_{4}$ cell. This bulk deposition was necessary as UPD does not occur at the beginning of the reaction. The working electrode was then immersed into the third cell where $\mathrm{Cu}$ was galvanically replaced by $\mathrm{Pd}$ under the open circuit potential $(\mathrm{OCP})$. Once the monolayer of Pd was prepared, the UPD among $\mathrm{Cu}$ and Pd was carried out in controlled manner. Finally, the prepared Pd/CNx-HMMT electrode was washed with double distilled water before conducting other electrochemical measurements.

\subsection{Characterization Techniques}

\subsubsection{Fourier Transform Infrared Spectroscopy (FTIR)}

The FTIR study of all synthesized samples was done using an IR Prestige-21 (Shimadzu) applying an attenuated total reflectance (ATR) accessory equipped with zinc selenide (ZnSe) crystal. Before each measurement, an air background of the instrument was run in order to make analysis more reliable. The frequency range was set at 4000 to $400 \mathrm{~cm}^{-1}$ with the resolution of $4.0 \mathrm{~cm}^{-1}$. Average of 64 scans per spectrum were recorded. 


\subsubsection{X-ray Diffraction Measurements (XRD)}

$\mathrm{X}$-ray diffraction (XRD) is a quick analytical procedure mainly employed to identify the phases of a crystalline substance, which can give information about the dimensions of a unit cell. The XRD patterns were obtained at ambient temperature $\mathrm{Cu}$ Ka radiation $(\lambda=1.5418 \AA), 35 \mathrm{kV}$ voltage, and $30 \mathrm{~mA}$ current with from $0^{\circ}$ to $100^{\circ}$ scanning range. The PANalytical X-ray system was used for crystallographic framework studies. Some samples were also analyzed using X'Pert Proanlytical X-ray diffractometer.

\subsubsection{Scanning Electron Microscopy (SEM) and Transmission Electron Microscopy (TEM)}

This characterization technique was utilized to analyze the surface characteristics and grain size of the given material [33,37] (LEO 1530 scanning electron microscope (SEM)). Before measurement, each sample was sputtered with gold for about $120 \mathrm{~s}$ prior to SEM analysis in order to assure that there was no charge present on the sample surface. The SEM instrument is provided with energy dispersive X-ray spectrometer (EDS) and transmission electron microscopy (TEM). The chemical compositions of the Pd/CNx-MMT catalysts were determined using inductively coupled plasma atomic emission spectroscopy (ICP-AES) system.

\subsubsection{Cyclic Voltammetry (CV)}

The electrochemical measurements were performed using a typical three-electrode cell at room temperature $[34,38]$. The electrochemical measurements of all prepared samples were carried out using a Pine WaveNowXV potentiostat, commercial $20 \mathrm{wt} \% \mathrm{Pd} / \mathrm{C}$ supplied by E-TEK, Co. was also tested as reference material [39]. In a typical procedure, catalyst ink was synthesized by adding $5 \mathrm{mg}$ of prepared electrocatalysts in $1 \mathrm{~mL}$ of Nafion/ethanol ( $0.25 \%$ Nafion) mixture. Approximately 8 to $10 \mu \mathrm{L}$ of the dispersion was moved onto the glassy carbon disc using a pipette and then allowed to dry completely at ambient conditions. The resultant catalyst loading was $0.455 \mathrm{mg} \mathrm{cm}^{-2}$. The mass percentage (20 wt \%) of $\mathrm{Pd}$ in the $\mathrm{Pd} / \mathrm{C}$ and $\mathrm{Pd} / \mathrm{CNx}-\mathrm{HMMT}$ catalysts as well as the $\mathrm{Pd}$ particle size $(4-5 \mathrm{~nm})$ are the same in the two materials. A conventional three-electrode system was adopted, in which MMT-CNx modified glassy carbon electrode (5 $\mathrm{mm}$ in diameter) as the working electrode while $\mathrm{Pt}$ wire, and $\mathrm{Ag} / \mathrm{AgCl}$ were used as the counter electrode, and reference electrode respectively. The CVs of Pd/C and Pd/CNx-HMMT were carried out in $\mathrm{N}_{2}$ saturated solution of $0.5 \mathrm{~mol} \mathrm{~L}^{-1} \mathrm{H}_{2} \mathrm{SO}_{4}$ and $0.5 \mathrm{~mol} \mathrm{~L}^{-1} \mathrm{MeOH}$ at a scan rate of $20 \mathrm{mV} / \mathrm{s}$ at ambient temperature. All the $\mathrm{CV}$ experiments were performed at room temperature and in an $\mathrm{O}_{2}$-free atmosphere by bubbling the electrolyte with high purity $\mathrm{N}_{2}$ for $30 \mathrm{~min}$.

\section{Results and Discussion}

\subsection{FTIR Spectroscopy}

FTIR analysis was used to investigate the interactions between the polyaniline (PANI) and acid activated montmorillonite (HMMT) and chemical structure of composite electrode materials. Figure 2 exhibits the FTIR spectra of pure HMMT, PANI/HMMT nanocomposites, CNx-HMMT, and Pd/CNx-HMMT. From the HMMT spectra, the strong absorptions that appeared at $1039(\mathrm{Si}-\mathrm{O}-\mathrm{Si}), 915(\mathrm{Al}-\mathrm{OH})$ and $520-464 \mathrm{~cm}^{-1}(\mathrm{Si}-\mathrm{O}-\mathrm{Al})$ were assigned the characteristic bands of pure HMMT [40].

From the PANI-HMMT composite spectra, some additional absorption bands were observed at $832,1290,1498$ and $1573 \mathrm{~cm}^{-1}$ corresponding to the $\mathrm{C}-\mathrm{H}, \mathrm{C}-\mathrm{N}$, benzene ring and quinine ring respectively. These bands are characteristics of polyaniline (PANI) [41]. The successful preparation of the PANI-HMMT nanocomposites is confirmed from the recurrence of characteristic HMMT and polyaniline bands in PANI-HMMT nanocomposite spectra. As for the CNx-MMT and Pd/CNx-HMMT samples, there are obvious peaks at about 1625 and $1410 \mathrm{~cm}^{-1}$, which are associated to the aromatic $\mathrm{C}-\mathrm{C}$ bonds in sp $\mathrm{s}^{2}$ configuration and stretching vibrations of $\mathrm{C}-\mathrm{N}$ bond respectively. It was found that the other peaks of HMMT and PANI appeared decreased after carbonization temperature. In addi- 
tion, when the temperature was above $800{ }^{\circ} \mathrm{C}$, the PANI-HMMT composite decomposed completely $[17,37]$.

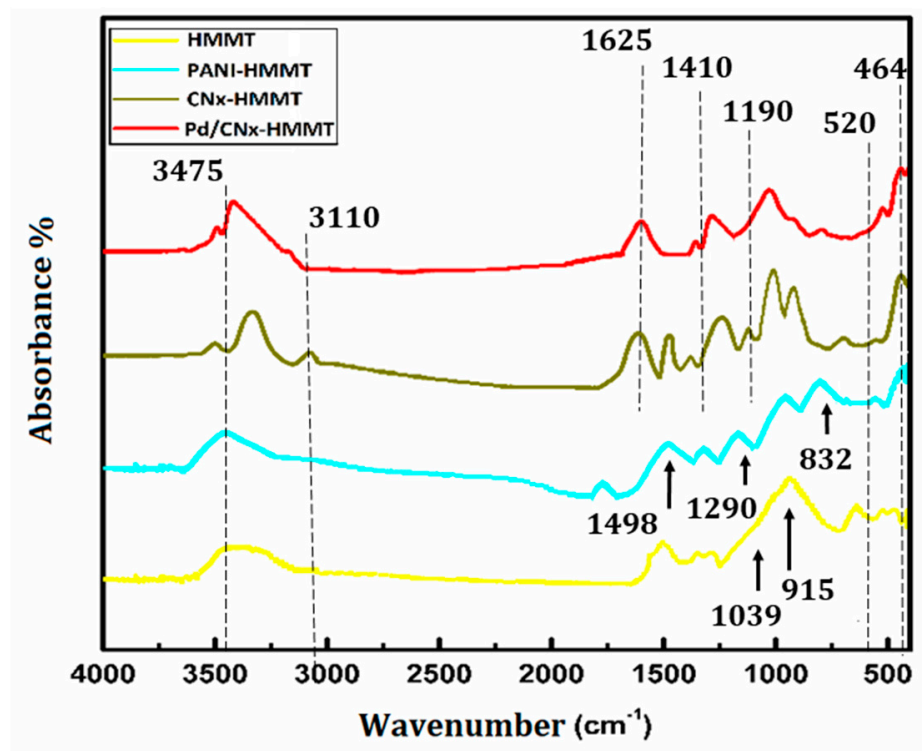

Figure 2. FTIR spectra of HMMT, PANI-HMMT, CNx-HMMT, and Pd/CNx-HMMT.

\subsection{X-ray Diffraction}

Figure 3 shows the XRD pattern of HMMT, CNx-HMMT and Pd/CNx-HMMT. From the XRD pattern of HMMT, the prominent quartz peaks appear at $2 \theta=20.1^{\circ}$ and $26.8^{\circ}$. In addition to that, other weak reflections were also observed that indicated the acid treatment dissolves octahedral cations $\left(\mathrm{Al}^{3+}, \mathrm{Mg}^{2+}\right.$, and $\left.\mathrm{Fe}^{3+}\right)$ of MMT crystal structure which resulted in the destruction of MMT octahedral crystal structure and the subsequent strengthening of quartz diffraction peak $[42,43]$. The in-situ polymerization of aniline resulted in the formation PANI-HMMT composite which lowered the intensities of HMMT peaks, although peaks become less intense but still present that exhibited the preservation of basic clay framework even after the development of composite structure. This also confirmed the uniform distribution of HMMT on polymer matrix.

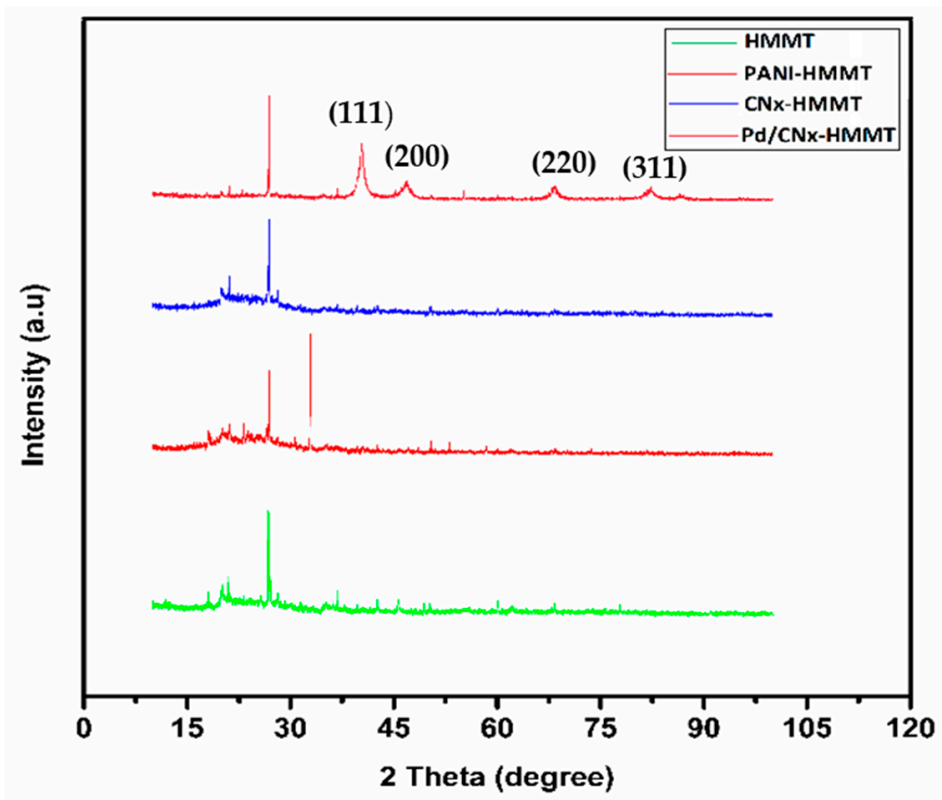

Figure 3. XRD patterns of HMMT, PANI-HMMT, CNx-HMMT, and Pd/CNx-HMMT. 
In the case of CNx-HMMT, the position of the characteristic diffraction quartz peaks did not change. A new broad diffraction peak was observed at $2 \theta=20-25^{\circ}$, associated with the plane (200) of carbon. However, the heat treatment destroyed the HMMT octahedral structure which was shown by the vanishing of (001) peak in CNx-HMMT. The CNxHMMT composites exhibited the similar diffraction peaks of HMMT in the range of $2 \theta=20^{\circ}-40^{\circ}$, confirm that after heat treatment structural features of HMMT was still preserved. It is concluded from XRD results that HMMT maintained its stability for preparing the CNx-HMMT catalyst [44].

The Pd nanoparticles were chosen to find out the influence of the support CNxHMMT on the catalytic activity of resultant catalyst. The crystal structure of Pd deposited at the surface of CNx-HMMT was characterized using XRD (Figure 3). The results showed that in the Pd/CNx-HMMT composite the characteristics HMMT diffraction peaks at $2 \theta=20.1^{\circ}$ and 26.8 were also observed clearly after Pd deposition on its surface. This indicates the structural stability of HMMT during the synthetic process for $\mathrm{Pd} / \mathrm{CNx}-\mathrm{HMMT}$. The characteristic Pd peaks (face-centered cubic (fcc)) were observed at $2 \theta=40.1^{\circ}(111), 46.7^{\circ}(200), 68.1^{\circ}(220)$, and $82.1^{\circ}(311)$, indicating the successful deposition of Pd on CNx-HMMT $[45,46]$. However, the occurrence of HMMT and CNx in Pd/CNxHMMT composites greatly weakened the diffraction peaks of Pd.

\subsection{Morphological Analysis}

As evident in Figure 4I a pristine HMMT presented very flaky texture exhibiting its layered morphology.

It was seen that the acid-treated HMMT have an irregular morphology with very rough surfaces. From Figure 4Ib the separated HMMT block or flakes were seen under the coverage of polyaniline (PANI) and very rough surface morphology was observed. These findings reinforced the successful preparation of PANI-HMMT composite and showed good compatibility among the two constituents [47]. Moreover, it is also a proof of homogenous distribution of both HMMT and PANI over each other [48].

From Figure 4Ic the CNx-HMMT displayed a coral shape morphology after carbonizing. The representative layered structure could be seen in CNx-HMMT, which is not observed in HMMT and PANI-HMMT. From Figure 4Id, SEM images of the Pd/CNx-HMMT catalyst exhibits the uniformed distribution of Pd particles on the CNx-HMMT support.

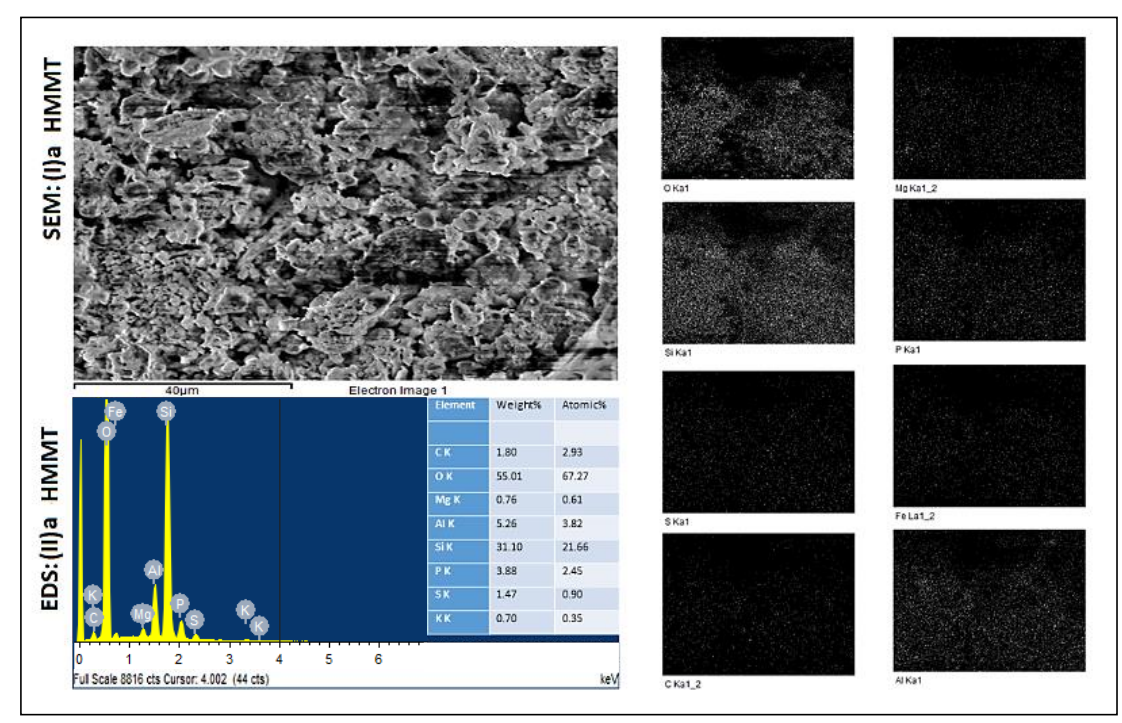

Figure 4. Cont. 

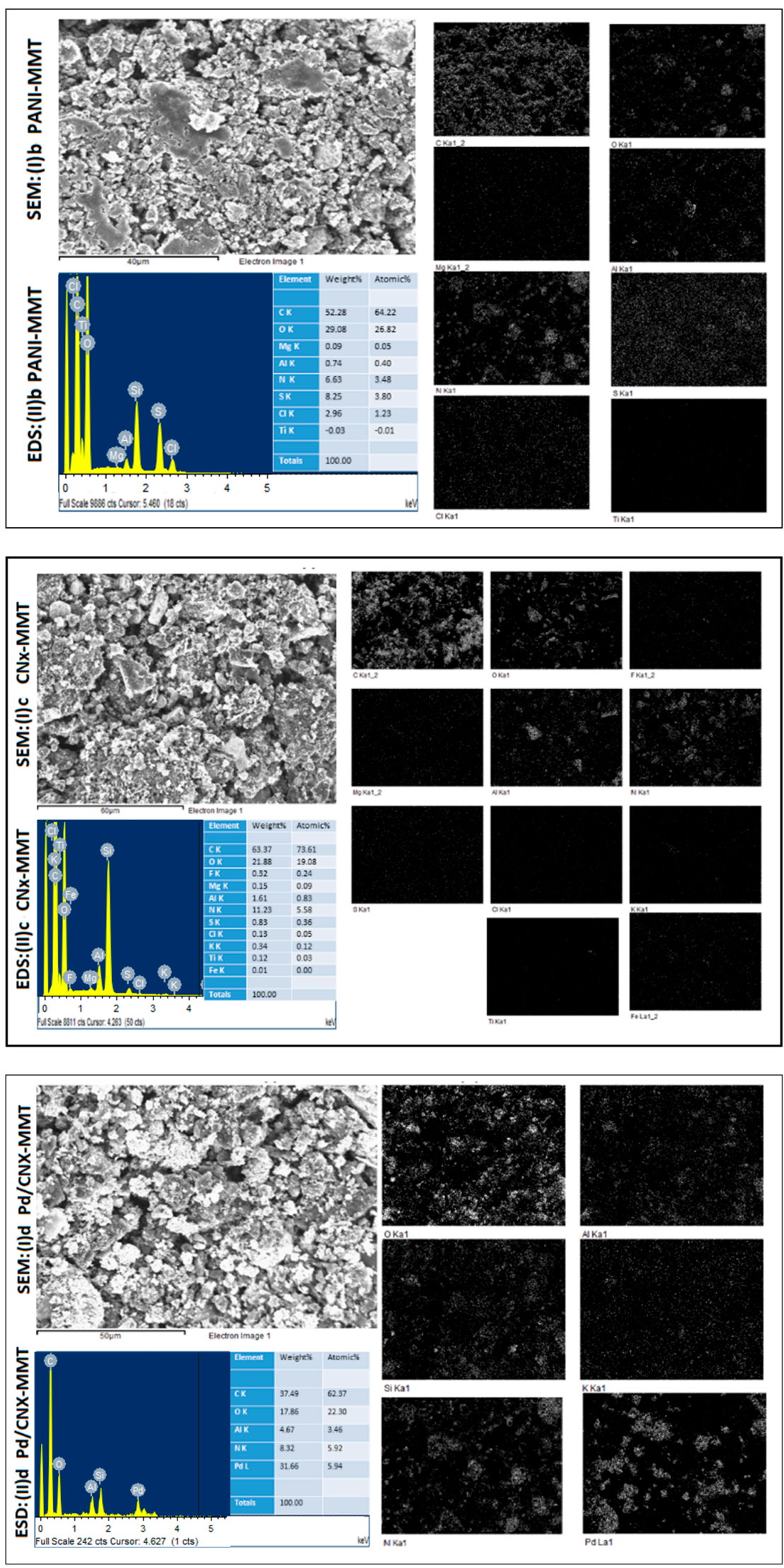

Figure 4. (I) SEM images of (I)a HMMT, (I)b PANI-HMMT (I)c CNx-HHMT, (I)d Pd/CNx-HHMT and 4(II) EDX of (II)a HMMT, (II)b PANI-HMMT (II)c CNx-HHMT, (II)d Pd/CNx-HHMT. 
The composition of HMMT, CNx-HMMT and Pd/CNx-HMMT was examined using energy-dispersive x-ray spectroscopy (EDS). Figure 4IIa showed that HMMT consist of C (1.8 wt \%), O (55.01 wt \%), Mg (0.76 wt \%), Si (31.10 wt \%), and $1.47 \mathrm{wt} \%$ and $0.70 \mathrm{wt} \%$ of $\mathrm{P}$ and $\mathrm{K}$ respectively whereas Figure 4IIb showed that in PANI-HMMT major contribution came from 52 wt \% carbon element along with nitrogen, oxygen, and some other clay related elements. While the EDX spectrum of CNx-HMMT shown in Figure 4IIc identifies the presence of higher percentage of C (almost $64 \mathrm{wt} \%), \mathrm{N}(11 \mathrm{wt} \%), \mathrm{O}(21 \mathrm{wt} \%)$ and some amount of $\mathrm{Si}$ and $\mathrm{Al}$ elements is also present. Other elements, including $\mathrm{Mg}$ and $\mathrm{Fe}$, are found in too low content. The EDS of Pd/CNx-HMMT showed the presence of Pd in the prepared electrode material with $31 \mathrm{wt} \%$ of the total elements (Figure 4IId).

TEM analysis of HMMT, PANI-HMMT, and Pd/CNx-HMMT materials has been also carried out and reported in Figure 5. In the image of Figure 5b the PANI-MMT show darkest color areas, which are denser than those of the pure HMMT reported in Figure 5a. Such a result demonstrates that HMMT platelets are fully intercalated within PANI matrix. From Figure $5 \mathrm{c}$ it is clear that Pd nanoparticles are well-dispersed on the top of the CNxMMT framework in a large amount with an average diameter of $4.15 \mathrm{~nm}$. Furthermore, in the TEM image the carbon layer and MMT seemed strongly adhered, implying that good contact between the two supports could promote the flow of fuel, oxidant, and electrons. In the Pd/CNx-HMMT, nanoparticle aggregation on the carbon surface has been observed.
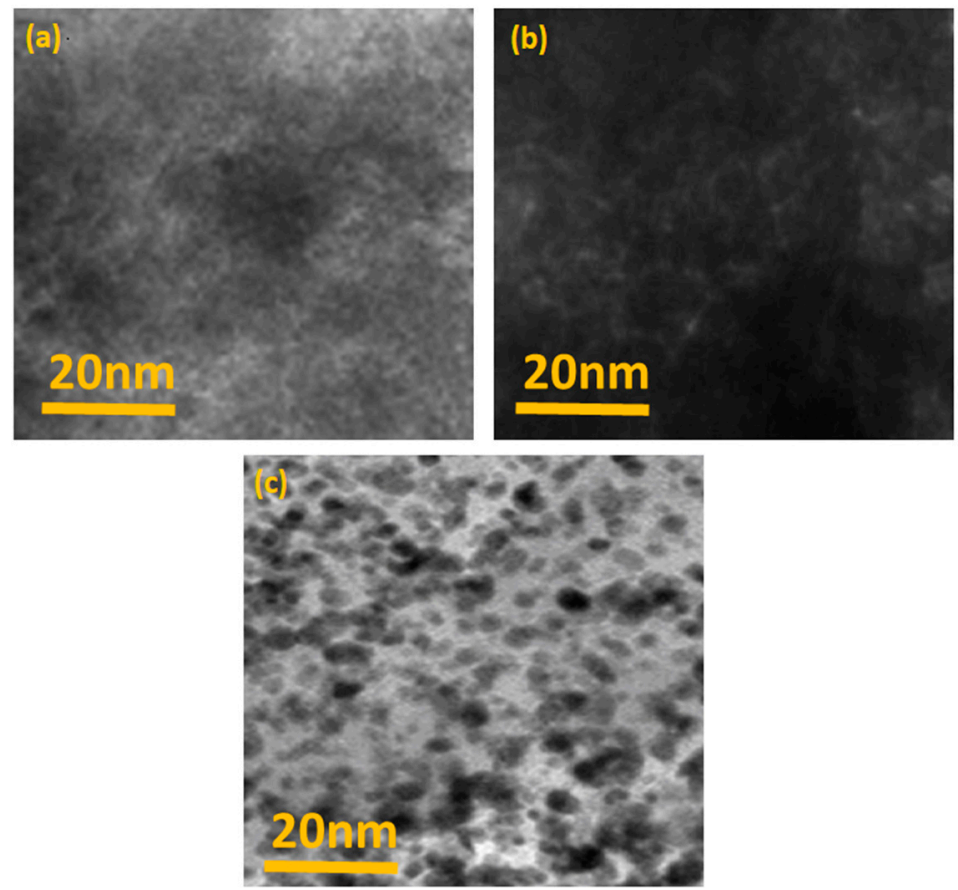

Figure 5. TEM images of (a) HMMT, (b) PANI-HMMT and (c) Pd/CNx-HMMT.

Concerning the commercial Pd/C electrocatalyst, the particle size is estimated by TEM analysis to be ca. $5 \mathrm{~nm}$ in a previous paper [39]. The inductively coupled plasma atomic emission spectroscopy (ICP-AES) has been also used to estimate the deposited percentage of Pd (21 wt \% of the total catalyst) and the average size of Pd nanoparticles deposited on the surface of CNx-MMT support (ca. $5.7 \mathrm{~nm}$ ). The results are in agreement with the above discussed EDX and TEM analysis.

\subsection{Cyclic Voltammograms (CVs)}

Figure 6 exhibited the cyclic CVs of pristine Pd/C and Pd/CNx-HMMT composite electrodes using $0.5 \mathrm{~mol} \mathrm{~L}^{-1} \mathrm{H}_{2} \mathrm{SO}_{4}$ solution with voltage ranged from 0.0 to.1.2 $\mathrm{V}$ at the room temperature. The scan rate applied was $50 \mathrm{mV} \mathrm{s}^{-1}$. The $\mathrm{CV}$ curve of both catalysts showed three major peaks associated with adsorption/desorption of hydrogen, formation 
of oxides/stripping wave and development of a flat double layer in lower potential region, higher potential region and in between region, respectively. In the case of Pd/CNx-HMMT catalyst, the double layer was wider in comparison with that of the $\mathrm{Pd} / \mathrm{C}$. This showed the existence of more defective active site at CNx-HMMT surface which facilitates the $\mathrm{Pd}$ nanoparticle adsorption and helpful in electron transfer. The Pd/CNx-HMMT also possessed larger electrochemically accessible area (ESA) as compared to $\mathrm{Pd} / \mathrm{C}$ according to fashion of double-layer, which would be helpful toward the access for solvated and charged ions at nitrogen-doped support. In light of the CV results, it is anticipated that the $\mathrm{Pd} / \mathrm{CNx}-\mathrm{MMT}$ may present high electrocatalytic performance compared to Pd/C.

The electrochemical active surface area (ECSA) value was used to obtain valuable evidence regarding the expanse of electrochemically active sites of precious metal. It is also a key parameter for assessing the electrochemical activity of various electrocatalytic supports [49]. ECSA of $\mathrm{Pd} / \mathrm{C}$ and $\mathrm{Pd} / \mathrm{CNx}-\mathrm{MMT}$ were calculated using the following equation [50]:

$$
E C S A=Q_{H} / 210 \times M_{P t}
$$

where $\mathrm{Q}_{\mathrm{H}}\left(\mathrm{cm}^{-2}\right)$ is the charge exchanged during the electroadsorption of hydrogen on $\mathrm{Pd}$ at the potential range of -0.13 to $+0.2 \mathrm{~V}$ (vs. $\mathrm{Ag} / \mathrm{AgCl}), 210$ is the charge $\left(\mu \mathrm{cm}^{-2}\right.$ ) necessary to oxidize a monolayer of hydrogen at Pd surface and $M_{P t}$ is the $\mathrm{Pd}$ mass loading on the electrode. The specific ECSA as found were $13.01 \mathrm{~m}^{2} \mathrm{~g}^{-1}$ for $\mathrm{Pd} / \mathrm{C}$ and $23.00 \mathrm{~m}^{2} \mathrm{~g}^{-1}$ for $\mathrm{Pd} / \mathrm{CNx}-\mathrm{HMMT}$, respectively. The higher ECSA value found for $\mathrm{Pd} / \mathrm{CNx}-$ MMT can account the presence of more electrochemically active sites available for methanol oxidation.

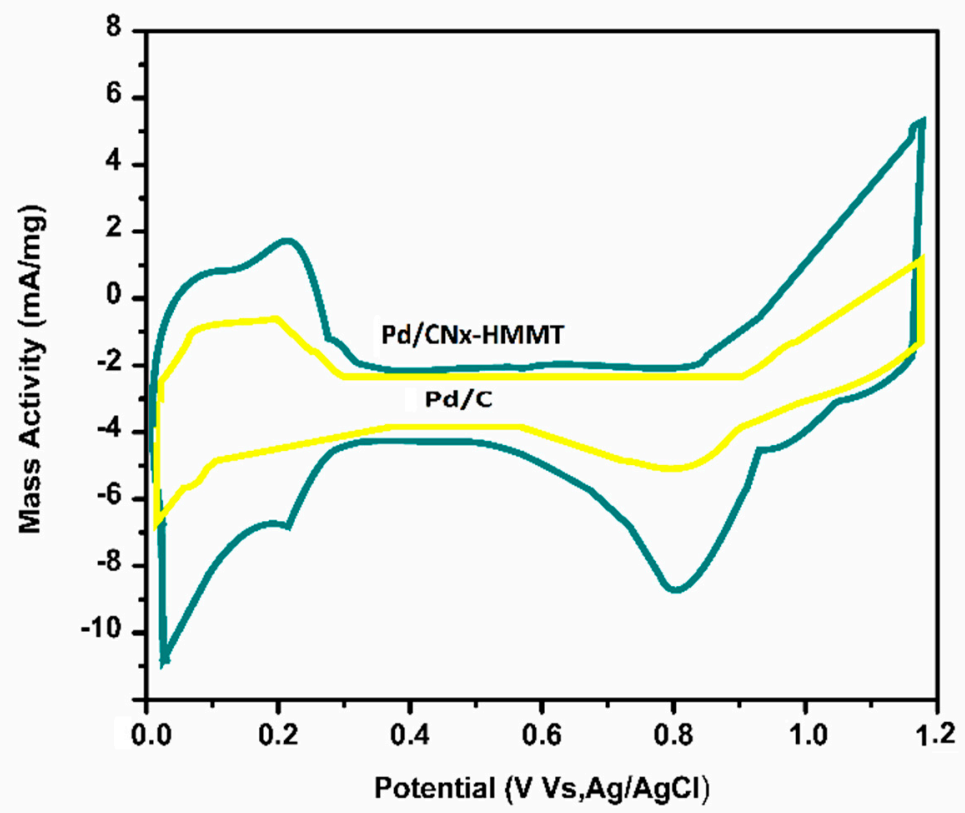

Figure 6. Cyclic voltammograms (CVs) of Pd/C and Pd/CNx-HMMT.

\subsection{Methanol Oxidation}

The methanol oxidation reaction on $\mathrm{Pd} / \mathrm{C}$ alone and $\mathrm{Pd} / \mathrm{CNx}-\mathrm{HMMT}$ composite material is presented in Figure 7. The test was conducted in a mixture of $\mathrm{H}_{2} \mathrm{SO}_{4}$ $\left(0.5 \mathrm{~mol} \mathrm{~L}^{-1}\right)+\mathrm{CH}_{3} \mathrm{OH}\left(0.5 \mathrm{~mol} \mathrm{~L}^{-1}\right)$ solution with $50 \mathrm{mV} \mathrm{s}^{-1}$ at ambient temperature [51]. 


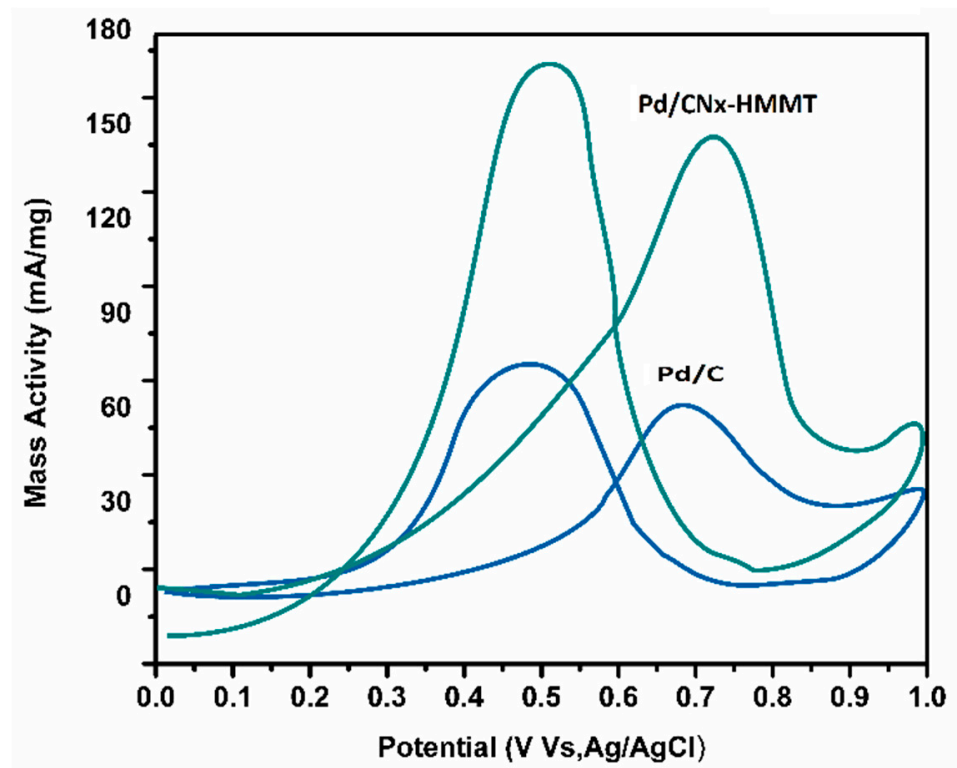

Figure 7. Methanol oxidation cyclic voltammograms of prepared electrodes ( $\mathrm{Pd} / \mathrm{C}$ and $\mathrm{Pd} / \mathrm{CNx}-$ HMMT MOR electrocatalysts).

The forward peak and the onset potential of $\mathrm{Pd} / \mathrm{CNx}$-MMT catalysts are compared in Table 1 with the reference material $\mathrm{Pd} / \mathrm{C}$ and with literature data relating to $\mathrm{Pt}$ - based benchmark materials [52-54]. It can be observed that the Pd/CNx-HMMT catalyst depicted lower onset potential of methanol oxidation and a forward peak potential similar to $\mathrm{Pt}$ based electrocatalysts and more positive than that of commercial Pd/C. Moreover, the $\mathrm{Pd} / \mathrm{CNx}-\mathrm{HMMT}$ exhibited 2.3 times higher peak oxidation current than that of $\mathrm{Pd} / \mathrm{C}$.

Table 1. Comparison of the electrochemical performance toward methanol oxidation between the Pd/CNx-MMT catalyst proposed in this work and Pt-based benchmark materials studied in literature at the same experimental conditions.

\begin{tabular}{ccccc}
\hline Catalyst & Onset Potential, $\mathbf{V}$ & Forward Peak Potential, $\mathbf{~}$ & $\mathbf{I}_{\mathbf{f}} / \mathbf{I}_{\mathbf{b}}$ & References \\
\hline $\mathrm{Pt} / \mathrm{C}$ & 0.35 & 0.67 & 0.83 & {$[52]$} \\
$\mathrm{Pt} / \mathrm{TiO}_{2} @ \mathrm{C}-900$ & 0.25 & 0.77 & 0.62 & {$[53]$} \\
$\mathrm{Pt} / \mathrm{Vulcan} \mathrm{XC}-72 \mathrm{R}$ & 0.25 & 0.72 & 0.49 & {$[53]$} \\
$\mathrm{Pt} / \mathrm{C} 40-\mathrm{CeO}_{2}$ & 0.35 & 0.71 & 0.86 & {$[54]$} \\
$\mathrm{Pd} / \mathrm{CNx}-\mathrm{MMT}$ & 0.12 & 0.73 & 0.88 & This work \\
$\mathrm{Pd} / \mathrm{C}$ & 0.28 & 0.67 & 0.82 & This work \\
\hline
\end{tabular}

Being the mass percentage and size of $\mathrm{Pd}$ in $\mathrm{Pd} / \mathrm{C}$ and $\mathrm{Pd} / \mathrm{CNx}-\mathrm{HMMT}$ catalysts about the same ( $20 \mathrm{wt} \%$ and $4-5 \mathrm{~nm}$, respectively) the improved electrocatalytic activity is indicative of the availability of a greater number of catalytically active sites on $\mathrm{Pd} / \mathrm{CNx}$ HMMT for methanol oxidation in agreement with ESA measurements.

The catalyst tolerance toward accumulated carbonaceous species has been measured by estimating the ratio of the $\mathrm{I}_{\mathrm{f}}$ (forward anodic peak current) to $\mathrm{I}_{\mathrm{b}}$ (reverse anodic peak current). If the ratio is higher, it means the catalyst has higher power to eliminate harmful species from the surface. The $\mathrm{I}_{\mathrm{f}} / \mathrm{I}_{\mathrm{b}}$ ratios for $\mathrm{Pd} / \mathrm{CNx}-\mathrm{HMMT}$ and $\mathrm{Pd} / \mathrm{C}$ were 0.88 and 0.82 , respectively. The values are similar to the benchmark $\mathrm{Pt} / \mathrm{C}$ electrocatalyst, and higher than other composite Pt-based materials (Table 1); however, in the comparison attention has to be paid to the recent controversial hypothesis that correlated the $\mathrm{I}_{\mathrm{f}} / \mathrm{I}_{\mathrm{b}}$ ratio of MOR on platinum electrocatalysts to the degree of oxophilicity or to the formation/reduction of $\mathrm{Pt}$ oxides rather than $\mathrm{CO}$ tolerance $[55,56]$.

Chronoamperometric curves for $\mathrm{Pd} / \mathrm{C}$ and $\mathrm{Pd} / \mathrm{CNx}-\mathrm{HMMT}$ were attained to find out the effect of $\mathrm{CO}$ adsorption during methanol oxidation reaction (MOR) and shown in Figure 8. 


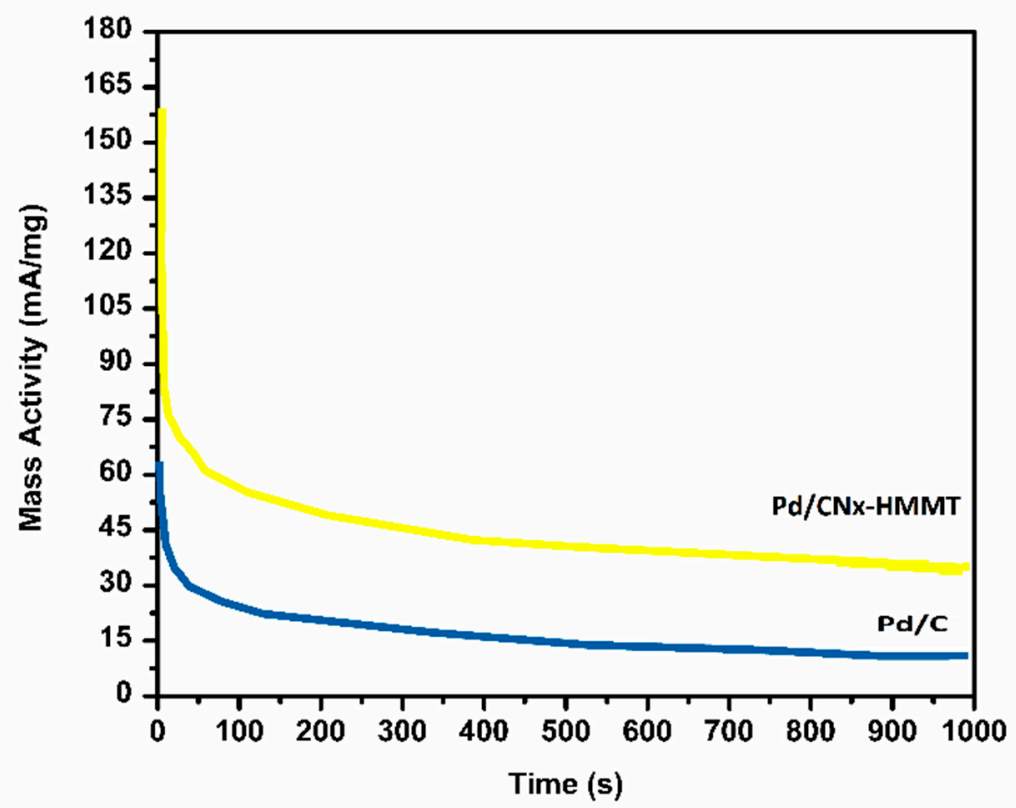

Figure 8. Chronoamperometric data of Pd/C and Pd/CNx-HMMT MOR electrocatalysts.

The methanol oxidation was carried out at the active sites of the catalysts by maintaining the electrode over a constant potential of $0.5 \mathrm{~V}$ (vs. $\mathrm{Ag} / \mathrm{AgCl}$ ) at ambient temperature. The methanol oxidation resulted in the production of $\mathrm{CO}$ intermediates that can occupy the active sites of Pd nanoparticles, and lead toward lowering of electrocatalytic activity [57]. In the case of Pd/CNx-HMMT catalyst for methanol oxidation, the current density remained greater as compared to pure $\mathrm{Pd} / \mathrm{C}$ catalyst. Moreover, all curves reach a steady state after about $1000 \mathrm{~s}$.

By evaluating the ratio of the current at 1000s $\left(\mathrm{I}_{1000}\right)$ and $100 \mathrm{~s}\left(\mathrm{I}_{100}\right)$, the long-term poisoning rates of both catalysts (Pd/C and $\mathrm{Pd} / \mathrm{CNx}-\mathrm{HMMT})$ were also determined. The ratios of $\mathrm{I}_{1000} / \mathrm{I}_{100}$ for $\mathrm{Pd} / \mathrm{CNx}-\mathrm{HMMT}$ and $\mathrm{Pd} / \mathrm{C}$ were found to be $52.5 \%$ and $26.1 \%$ respectively. The results exhibited that the $\mathrm{Pd} / \mathrm{CNx}-\mathrm{HMMT}$ electrocatalyst has greater stability as compared to pure $\mathrm{Pd} / \mathrm{C}$ electrocatalyst.

By considering that the Pd mass loading and particle size is almost the same in the two materials, the enhanced electrocatalytic activity and stability of $\mathrm{Pd} / \mathrm{CNx}-\mathrm{HMMT}$ can be entirely attributed to the effect of the novel CNx-HMMT support $[23,58]$. The results of this work demonstrated that one effect is surely the increase of ESA, nevertheless the interaction of Pd nanoparticles with the support and/or the formation of $\mathrm{C}-\mathrm{N}$ or bonds $\mathrm{Pd}-\mathrm{N}$ may also have a beneficial role in the MOR catalysis. Indeed, the incorporation of nitrogen, as demonstrated by the FTIR analysis, resulted in the effective introduction of chemically active sites into the carbon able to anchor the metal. The encouraging MOR electrocatalytic results of this work by using CNx-MMT as a novel support for Pd nanoparticles deposited by UPS open the way to future studies devoted to the deepening of the mechanistic aspects, i.e., identification of the active sites, that could shed light on the effects of the CNx-MMT material at the molecular scale on the half-reaction electrokinetic.

\section{Conclusions}

This work involved in the synthesis of nitrogen-doped montmorillonite (CNx-MMT) support for methanol oxidation electrocatalysts. The nitrogen doped montmorillonite (CNxMMT) that was used as support instead of conventional carbon black and Pd nanoparticles was deposited using the underpotential deposition method over the CNx-MMT support to form the Pd/CNx-MMT anode electrocatalyst for methanol oxidation in DMFC. The successful formation of Pd/CNx-MMT catalyst was confirmed using structural analysis (FTIR, XRD). The morphological studies confirmed a uniform distribution of Pd particles on the CNx-HMMT support. TEM images showed that the MMT and the carbon layer 
appeared well attached with each other, therefore facilitating the transport of fuel, oxidant and electrons and make this CNx-MMT material suitable as a support for electrocatalysts. The Pd/CNX-MMT catalysts exhibited excellent electrocatalytic activity toward methanol oxidation, thereby demonstrating their potential for DMFC application. The results also showed the long-term stability of Pd/CNx-MMT catalysts toward methanol oxidation than commercial Pd/C.

Author Contributions: Conceptualization, F.A. and K.J.; methodology, F.A. and K.J.; formal analysis, F.A., P.B. and K.J.; investigation, R.G.; data curation, F.A., R.B., R.G., M.U.H. and G.A.; writingoriginal draft preparation, F.A., R.B., R.G., M.U.H. and G.A.; writing-review and editing, F.A., P.B. and K.J.; supervision, F.A. and K.J. All authors have read and agreed to the published version of the manuscript.

Funding: This research received no external funding.

Institutional Review Board Statement: Not applicable.

Informed Consent Statement: Not applicable.

Data Availability Statement: The data presented in this study are available on request from the corresponding author.

Acknowledgments: The authors are grateful to the Higher Education Commission (HEC) Pakistan for the research grant through its 'International Research Support Initiative Program' (IRSIP) at Georgia Tech University, Atlanta, USA.

Conflicts of Interest: The authors declare no conflict of interest.

\section{References}

1. Gong, L.; Yang, Z.; Li, K.; Xing, W.; Liu, C.; Ge, J. Recent development of methanol electrooxidation catalysts for direct methanol fuel cell. J. Energy Chem. 2018, 27, 1618-1628. [CrossRef]

2. Berber, M.R.; Fujigaya, T.; Nakashima, N. A potential polymer formulation of a durable carbon-black catalyst with a significant fuel cell performance over a wide operating temperature range. Mater. Today Energy 2018, 10, 161-168. [CrossRef]

3. Devi, A.U.; Divya, K.; Rana, D.; Saraswathi, M.S.A.; Nagendran, A. Highly selective and methanol resistant polypyrrole laminated SPVdF-co-HFP/PWA proton exchange membranes for DMFC applications. Mater. Chem. Phys. 2018, 212, 533-542. [CrossRef]

4. Hu, Q.-Y.; Luo, L.-M.; Zhang, R.-H.; Chen, D.; Guo, Y.-F.; Zhan, W.; Zhou, X.W. Hydrothermal synthesis of complex morphological bimetal PdRh nanocatalysts for methanol oxidation. J. Alloy. Compd. 2020, 818, 152886. [CrossRef]

5. Ojani, R.; Hasheminejad, E.; Raoof, J.B. Direct growth of 3D flower-like Pt nanostructures by a template-free electrochemical route as an efficient electrocatalyst for methanol oxidation reaction. Energy 2015, 90, 1122-1131. [CrossRef]

6. Xie, Y.; Li, Z.; Liu, Y.; Ye, Y.; Zou, X.; Lin, S. Plasmon enhanced bifunctional electro-photo catalytic properties of Pt-Au/graphene composites for methanol oxidation and oxygen reduction reaction. Appl. Surface Sci. 2020, 508, 145161. [CrossRef]

7. Shahrokhian, S.; Rezaee, $\mathrm{S}$. Vertically standing $\mathrm{Cu}_{2} \mathrm{O}$ nanosheets promoted flower-like PtPd nanostructures supported on reduced graphene oxide for methanol electro-oxidation. Electrochim. Acta 2018, 259, 36-47. [CrossRef]

8. Soleimani-Lashkenari, M.; Rezaei, S.; Fallah, J.; Rostami, H. Electrocatalytic performance of Pd/PANI/TiO 2 nanocomposites for methanol electrooxidation in alkaline media. Synth. Met. 2018, 235, 71-79. [CrossRef]

9. Wang, Z.-B.; Zuo, P.-J.; Wang, G.-J.; Du, C.-Y.; Yin, G.-P. Effect of Ni on PtRu/C catalyst performance for ethanol electrooxidation in acidic medium. J. Phys. Chem. C 2008, 112, 6582-6587. [CrossRef]

10. Kwok, Y.; Wang, Y.; Tsang, A.C.; Leung, D.Y. Graphene-carbon nanotube composite aerogel with Ru@ Pt nanoparticle as a porous electrode for direct methanol microfluidic fuel cell. Appl. Energy 2018, 217, 258-265. [CrossRef]

11. Hanifah, M.F.R.; Jaafar, J.; Othman, M.; Ismail, A.; Rahman, M.; Yusof, N.; Aziz, F. One-pot synthesis of efficient reduced graphene oxide supported binary Pt-Pd alloy nanoparticles as superior electro-catalyst and its electro-catalytic performance toward methanol electro-oxidation reaction in direct methanol fuel cell. J. Alloy. Compd. 2019, 793, 232-246. [CrossRef]

12. Ren, J.; Zhang, J.; Yang, C.; Yang, Y.; Zhang, Y.; Yang, F.; Ma, F.; Yang, L.; He, H.; Huang, H. Pd nanocrystals anchored on 3D hybrid architectures constructed from nitrogen-doped graphene and low-defect carbon nanotube as high-performance multifunctional electrocatalysts for formic acid and methanol oxidation. Mater. Today Energy 2020, 16, 100409. [CrossRef]

13. Kang, Z.; Zhao, M.; Wu, Y.; Xia, T.; Cao, J.-P.; Cai, W.; Chen, L. Facial fabrication of yolk-shell Pd-Ni-P alloy with mesoporous structure as an advanced catalyst for methanol electro-oxidation. Appl. Surface Sci. 2019, 484, 441-445. [CrossRef]

14. Zhao, Y.; Zhan, L.; Tian, J.; Nie, S.; Ning, Z. Enhanced electrocatalytic oxidation of methanol on Pd/polypyrrole-graphene in alkaline medium. Electrochim. Acta 2011, 56, 1967-1972. [CrossRef]

15. Chen, D.; He, Z.; Pei, S.E.; Huang, L.A.; Shao, H.; Jin, Y.; Wang, J. Pd nanoparticles supported on N and P dual-doped graphene as an excellent composite catalyst for methanol electro-oxidation. J. Alloy. Compd. 2019, 785, 781-788. [CrossRef] 
16. Ruiz-Garcia, C.; Heras, F.; Calvo, L.; Alonso-Morales, N.; Rodriguez, J.; Gilarranz, M. Improving the activity in hydrodechlorination of Pd/C catalysts by nitrogen doping of activated carbon supports. J. Environ. Chem. Eng. 2020, 8, 103689. [CrossRef]

17. Wang, W.-D.; Lin, X.-Q.; Zhao, H.-B.; Lü, Q.-F. Nitrogen-doped graphene prepared by pyrolysis of graphene oxide/polyaniline composites as supercapacitor electrodes. J. Anal. Appl. Pyrolysis 2016, 120, 27-36. [CrossRef]

18. Vinayan, B.; Sethupathi, K.; Ramaprabhu, S. Facile synthesis of triangular shaped palladium nanoparticles decorated nitrogen doped graphene and their catalytic study for renewable energy applications. Int. J. Hydrog. Energy 2013, 38, 2240-2250. [CrossRef]

19. Asensio, J.A.; Borrós, S.; Gómez-Romero, P. Proton-conducting polymers based on benzimidazoles and sulfonated benzimidazoles. J. Polym. Sci. Part A Polym. Chem. 2002, 40, 3703-3710. [CrossRef]

20. Pan, Y.B.; Shen, X.C.; Yao, L.B.; Bentalib, A.; Peng, Z.M. Active sites in heterogeneous catalytic reaction on metal and metal oxide: Theory and practice. Catalysts 2018, 8, 478. [CrossRef]

21. Lippits, M.J.; Nieuwenhuys, B.E.; Iwema, R.R.H.B. A comparative study of oxidation of methanol on gamma- $\mathrm{Al}_{2} \mathrm{O}_{3}$ supported group IB metal catalysts. Catal. Today 2009, 145, 27-33. [CrossRef]

22. Kai, L.; Xuezhong, W.; Zexing, Z.; Xiaodong, W.; Duan, W. Oxygen storage capacity of Pt-, Pd-, Rh/CeO2-based oxide catalyst. J. Rare Earths 2017, 25, 6-10. [CrossRef]

23. Zhang, X.; Chen, X.; Liu, Y.; Guo, M. Effects of Support on Performance of Methanol Oxidation over Palladium-Only Catalysts. Water Air Soil Pollut. 2020, 231, 277. [CrossRef]

24. Hrachová, J.; Komadel, P.; Fajnor, V.Š. The effect of mechanical treatment on the structure of montmorillonite. Mater. Lett. 2007, 61, 3361-3365. [CrossRef]

25. Wang, J.; Sun, K.; Hao, W.; Du, Y.; Pan, C. Structure, and properties research on montmorillonite modified by flame-retardant dendrimer. Appl. Clay Sci. 2014, 90, 109-121. [CrossRef]

26. Herrero, M.; Núñez, K.; Gallego, R.; Merino, J.C.; Pastor, J.M. Control of molecular weight and polydispersity in polyethylene/needle-like shaped clay nanocomposites obtained by in situ polymerization with metallocene catalysts. Eur. Polym. J. 2016, 75, 125-141. [CrossRef]

27. Manikandan, D.; Divakar, D.; Rupa, A.V.; Revathi, S.; Preethi, M.E.L.; Sivakumar, T. Synthesis of platinum nanoparticles in montmorillonite and their catalytic behaviour. Appl. Clay Sci. 2007, 37, 193-200. [CrossRef]

28. Wang, J.; Zhu, Q.; Lu, X.; Meng, Y. ZnGA-MMT catalyzed the copolymerization of carbon dioxide with propylene oxide. Eur. Polym. J. 2005, 41, 1108-1114. [CrossRef]

29. Brankovic, S.R.; Zangari, G. Electrochemical Surface Processes and Opportunities for Material Synthesis. Electrochem. Eng. Across Scales Mol. Process. 2015. [CrossRef]

30. Zangari, G. Electrodeposition of alloys and compounds in the era of microelectronics and energy conversion technology. Coatings 2015, 5, 195-218. [CrossRef]

31. Tiwari, A.K.; Jain, S.; Mungray, A.A.; Mungray, A.K. $\mathrm{SnO}_{2}$ : PANI modified cathode for performance enhancement of air-cathode microbial fuel cell. J. Environ. Chem. Eng. 2020, 8, 103590. [CrossRef]

32. Pattanayak, P.; Pramanik, N.; Papiya, F.; Kumar, V.; Kundu, P.P. Metal-free keratin modified poly (pyrrole-co-aniline)-reduced graphene oxide-based nanocomposite materials: A promising cathode catalyst in microbial fuel cell application. J. Environ. Chem. Eng. 2020, 8, 103813. [CrossRef]

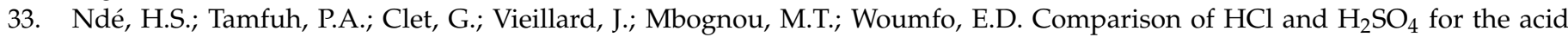
activation of a cameroonian smectite soil clay: Palm oil discolouration and landfill leachate treatment. Heliyon 2019, 5, e02926. [CrossRef] [PubMed]

34. Abbas, M.; Hachemaoui, A.; Yahiaoui, A.; Mourad, A.-H.I.; Belfedal, A.; Cherupurakal, N. Chemical synthesis of nanocomposites via in-situ polymerization of aniline and iodoaniline using exchanged montmorillonite. Polym. Polym. Compos. 2020. [CrossRef]

35. Kalotra, S.; Mehta, R. Synthesis of polyaniline/clay nanocomposites by in situ polymerization and its application for the removal of Acid Green 25 dye from wastewater. Polym. Bull. 2020, 78, 2439-2463. [CrossRef]

36. Kenane, A.; Galca, A.-C.; Matei, E.; Yahiaoui, A.; Hachemaoui, A.; Benkouider, A.M.; Bartha, C.; Istrate, M.C.; Galatanu, M.; Stanculescu, A.; et al. Synthesis and characterization of conducting aniline and o-anisidine nanocomposites based on montmorillonite modified clay. Appl. Clay Sci. 2020, 184, 105395. [CrossRef]

37. Goldstein, J.I.; Newbury, D.E.; Michael, J.R.; Ritchie, N.W.; Scott, J.H.J.; Joy, D.C. Scanning Electron Microscopy and X-ray Microanalysis; Springer: Berlin/Heidelberg, Germany, 2017.

38. Zhang, K.; Yang, W.; Ma, C.; Wang, Y.; Sun, C.; Chen, Y.; Chen, L.; Duchesne, P.; Zhou, J.; Wang, J.; et al. A highly active, stable and synergistic Pt nanoparticles/Mo 2 C nanotube catalyst for methanol electro-oxidation. NPG Asia Mater. 2015, 7, e153. [CrossRef]

39. Lee, Y.-W.; Han, S.-B.; Park, K.-W. Electrochemical properties of Pd nanostructures in alkaline solution. Electrochem. Commun. 2009, 11, 1968-1971. [CrossRef]

40. Marins, J.A.; Soares, B.G. A facile and inexpensive method for the preparation of conducting polyaniline-clay composite nanofibers. Synth. Met. 2012, 162, 2087-2094. [CrossRef]

41. Zhang, Y.; Shao, Y.; Zhang, T.; Meng, G.; Wang, F. High corrosion protection of a polyaniline/organophilic montmorillonite coating for magnesium alloys. Prog. Org. Coat. 2013, 76, 804-811. [CrossRef]

42. Li, Y.F.; Wang, Y.P.; Gao, X.H.; Gao, J.M. Composites of Polystyrene Sulfonic Acid (PSSA)-Polyaniline and Montmorillonite Clay: Synthesis and Characterization. J. Macromol. Sci. Part A 2006, 43, 405-415. [CrossRef] 
43. Abd El-Ghaffar, M.; Youssef, A.; Abd El-Hakim, A. Polyaniline nanocomposites via in situ emulsion polymerization based on montmorillonite: Preparation and characterization. Arab. J. Chem. 2015, 8, 771-779. [CrossRef]

44. Kim, B.-H.; Jung, J.-H.; Hong, S.-H.; Joo, J.; Epstein, A.J.; Mizoguchi, K.; Kim, J.W.; Choi, H.J. Nanocomposite of polyaniline and $\mathrm{Na}+-$ montmorillonite clay. Macromolecules 2002, 35, 1419-1423. [CrossRef]

45. Wei, Z.; Pan, R.; Hou, Y.; Yang, Y.; Liu, Y. Graphene-supported Pd catalyst for highly selective hydrogenation of resorcinol to 1 , 3-cyclohexanedione through giant $\pi$-conjugate interactions. Sci. Rep. 2015, 5, 15664. [CrossRef]

46. Xu, Y.; Ma, J.; Xu, Y.; Xu, L.; Xu, L.; Li, H. Palladium nanoparticles encapsulated in porous silica shells: An efficient and highly stable catalyst for CO oxidation. RSC Adv. 2013, 3, 851-858. [CrossRef]

47. Lee, D.; Char, K.; Lee, S.W.; Park, Y.W. Structural changes of polyaniline/montmorillonite nanocomposites and their effects on physical properties. J. Mater. Chem. 2003, 13, 2942-2947. [CrossRef]

48. Qureshi, U.A.; Gubbuk, I.H.; Ersoz, M.; Solangi, A.R.; Taqvi, S.I.; Memon, S.Q. Preparation of polyaniline montmorillonite clay composites for the removal of diethyl hexyl phthalate from aqueous solutions. Sep. Sci. Technol. 2016, 51, 214-228. [CrossRef]

49. Huang, H.; Wang, X. Pd nanoparticles supported on low-defect graphene sheets: For use as high-performance electrocatalysts for formic acid and methanol oxidation. J. Mater. Chem. 2012, 22, 22533-22541. [CrossRef]

50. Sun, Z.; Wang, X.; Liu, Z.; Zhang, H.; Yu, P.; Mao, L. PtRu/CeO $/$ /carbon nanotube nanocomposites: An efficient electrocatalyst for direct methanol fuel cells. Langmuir 2010, 26, 12383-12389. [CrossRef]

51. Li, Y.; Gao, W.; Ci, L.; Wang, C.; Ajayan, P.M. Catalytic performance of Pt nanoparticles on reduced graphene oxide for methanol electro-oxidation. Carbon 2010, 48, 1124-1130. [CrossRef]

52. Wu, X.; Zhuang, W.; Lu, L.; Li, L.; Zhu, J.; Mu, L.; Li, W.; Zhu, Y.; Lu, X. Excellent performance of Pt-C/TiO 2 for methanol oxidation: Contribution of mesopores and partially coated carbon. Appl. Surface Sci. 2017, 426, 890-896. [CrossRef]

53. Lee, J.-M.; Han, S.-B.; Kim, J.-Y.; Lee, Y.-W.; Ko, A.R.; Roh, B.; Hwang, I.; Park, K.W. TiO ${ }_{2} @$ carbon core-shell nanostructure supports for platinum and their use for methanol electrooxidation. Carbon 2010, 48, 2290-2296. [CrossRef]

54. Chu, Y.-Y.; Wang, Z.-B.; Jiang, Z.-Z.; Gu, D.-M.; Yin, G.-P. A novel structural design of a Pt/C-CeO 2 catalyst with improved performance for methanol electro-oxidation by cyclodextrin carbonization. Adv. Mater. 2011, 23, 3100-3104. [CrossRef]

55. Haisch, T.; Kubannek, F.; Nikitina, L.; Nikitin, I.; Pott, S.; Cleesc, T.; Krewer, U. The origin of the hysteresis in cyclic voltammetric response of alkaline methanol electrooxidation. Phys. Chem. Chem. Phys. 2020, 22, 16648-16654. [CrossRef]

56. Chung, D.Y.; Lee, K.-J.; Sung, Y.-E. Methanol Electro-oxidation on Pt Surface: Revisiting the Cyclic Voltammetry Intrepretation. J. Phys. Chem. C 2010, 120, 9028-9035. [CrossRef]

57. Huang, H.; Yang, S.; Vajtai, R.; Wang, X.; Ajayan, P.M. Pt-decorated 3D architectures built from graphene and graphitic carbon nitride nanosheets as efficient methanol oxidation catalysts. Adv. Mater. 2014, 26, 5160-5165. [CrossRef] [PubMed]

58. Bäumer, M.; Libuda, J.; Neyman, K.M.; Rösch, N.; Rupprechter, G. Hans-Joachim Freundb Adsorption and reaction of methanol on supported palladium catalysts: Microscopic-level studies from ultrahigh vacuum to ambient pressure conditions. Phys. Chem. Chem. Phys. 2007, 9, 3541-3558. [CrossRef] 